\title{
THE USE OF MOSS Pleurozium schreberi (Brid.) Mitt. AS BIOINDICATOR OF RADIONUCLIDE CONTAMINATION IN INDUSTRIAL AREAS OF UPPER SILESIA
}

\author{
WYKORZYSTANIE MCHÓW Pleurozium schreberi (Brid.) Mitt. \\ W BIOINDYKACJI SKAŻENIA RADIONUKLIDAMI OBSZARÓW \\ PRZEMYSEOWYCH GÓRNEGO ŚLĄSKA
}

\begin{abstract}
Mosses are good bioaccumulators of radionuclides and from the 60 of the last century, they are used as bioindicators of radioactive contamination in the environment. Concentration of impurities in moss represent the accumulation in mosses during the past 2-3 years. As a result, the moss composition analysis provides information on an average contamination within a few vegetation seasons. During our survey the measurements of radionuclide activity concentrations in $P$. schreberi transplanted from places relatively clean to heavily contaminated areas of Upper Silesia were carried out. An increase in the radionuclides activity concentrations in $P$. schreberi transplants may indicate not only deposition of the radionuclides itself, but also an influx of other pollutants. The results showed no relationship between the $\mathrm{Pb}-210$ activity concentration and activity concentrations of $\mathrm{Pb}-214, \mathrm{Bi}-214$, also belonging to the uranium-radium decay series. The increased concentration of $\mathrm{Pb}-210$ in $P$. schreberi may be the result of the radionuclide atmospheric deposition, which appears in the environment as a result of fossil fuels burning. Excess, allogeneic $\mathrm{Pb}-210$ can be used as marker of environmental pollution. In the areas with its higher activity concentration increased pollution can be expected delivered, for example, by local industry. The Project received financial assistance from the funds of the National Science Centre, granted by force of the decision no. UMO-2013/09/B/NZ8/03340 (NCN).
\end{abstract}

Keywords: bioindicator, radionuclides, moss $P$. schreberi

\section{Introduction}

Large amount of isotopes were released into the environment in the second half of the twentieth century. That was mainly due to tests of nuclear weapons carried out at the time as well as failures of nuclear installations. The intensive development of various branches of industry and power industry also causes enrichment of the environment with radioisotopes which are released to surrounding in industrial processes. For these reasons, it is necessary to conduct research of the possible hazards resulting from accumulation of

\footnotetext{
${ }^{1}$ Department of Ecology, Biogeochemistry and Environmental Protection, University of Wrocław, ul. Kanonia 6/8, 50-328 Wrocław, Poland, email: grzegorz.kosior@uwr.edu.pl

${ }^{2}$ Independent Department of Biotechnology and Molecular Biology, University of Opole, ul. kard. B. Kominka 6, 45-035 Opole, Poland

*Corresponding author: grzegorz.kosior@uwr.edu.pl
} 
natural and synthetic radionuclides in the environment as well as research pertaining to their retention, migration and circulation in food chains and impact on the biosphere.

Due to their long half-life and high bioavailability, some isotopes constitute a problem of special importance for the natural environment. However, the potential radioactive hazard was not the only motivation for conducting research. Since the routes and mechanisms of migration of radioisotopes and many other chemical compounds may be common, the radioactive isotopes may be convenient indicators of pollutants translocation coming from various sources.

Radioisotopes in the natural environment migrate in specific way, characteristic only to them. Released into the atmosphere, depending on the climatic conditions, they may migrate over considerable distances.

There are different pathways of radioisotopes migration in environment. For example, under some conditions, the deposited Cs-137 and $\mathrm{Pb}-210$ are accumulated in plants. They may also re-enrich the atmospheric aerosol through dust lifted from the soil, and can migrate over long distances, reaching even Arctic regions [1-4]. The only gaseous element in decay series, Rn-222, shows other mechanisms of translocation. Due to the ease of migration, this isotope may cause a disturbance of the local radioactive balance. Part of $\mathrm{Rn}-222$ is released from geological structures and undergoes further processes of decay in the atmosphere, causing the creation of other isotopes, including Pb-210 [5].

The Upper Silesia is the most urbanized region of Poland and one of the largest urban and industrial areas in Central Europe. Long-term exploitation of the natural resources of this area together with industrialization and urbanization has caused its physical and chemical degradation, which has in turn resulted in large geochemical anomalies.

Tight air quality regulations for industrial emitters have resulted in a clearly improved air quality in national and even continental scales. However, during the same time span, urbanization and both road and traffic density have increased significantly in the Upper Silesia region.

The main sources of increased natural radioactivity in the atmosphere are coal-fired power plants and coal mines. Coal contains about $1 \%$ of trace elements and radioisotopes. Fly ashes contains radioisotopes that are concentrated several times in comparison with their content in coal or surface soil. These radioisotopes, embedded in solid or liquid particles, return to the ground as dry fallout or washed out in rain [6-8].

The problem of contamination with radioisotopes of natural origin is still unsolved, and in some cases growing. Therefore, there is a continuing need to improve the methods of deposition analysis of these pollutants in the environment. Assessment of the environment pollution with use of living organisms is still very helpful in detecting both the risks and the changes taking place in areas under the influence of human impact. One way to determine the extent and degree of contamination is estimating of the xenobiotics level in plants.

Analysis of plants have many advantages in comparison to traditional non-living environment components analyzes such as water and soil. It was proven to be a precious mean to evaluate environmental quality and its administration [9-12].

The common application of mosses is mainly caused by their relative high efficiency in heavy metals and radioisotopes accumulation. Mosses do not have the epidermis and cuticle, which greatly facilitates the entry of contaminants into the cells. They have no roots, so they collect nutrients only from precipitation and dry deposition. It is assumed that concentration of chemical compounds in the moss's biomass corresponds to deposition from the air $[13,14]$. 
Air pollution biomonitoring with use of these plants is supported also by IAEA (International Atomic Energy Agency) in many countries within a coordinated research projects [15-17]. Terrestrial mosses are a promising medium for investigation and monitoring of airborne radioisotope depositions due to their widespread occurrence, ease of sampling, and the possibility of high-resolution gamma spectrometry measurements, without chemical treatment of samples [18-20].

The results of surveys show possibility of heavy metal cations translocation from soil to epigenetic moss and epiphytic lichens through dust lifted from the soil and, in the case of moss, through water that provides it with moisture [21].

Due to this accumulation, element concentrations determined in moss are much higher than in other sample materials such as precipitation, dust, or other plants and are thus easier to measure. Moreover, mosses can accumulate and concentrate toxic substances that may be present even in low concentrations in the local environment. Bryophytes are resistant against many substances which are highly toxic for other plants. The technique of analyzing the contents of contaminants in mosses is known as passive biomonitoring. Moss transplants have also been used as an active biomonitors [22-24]. Transplants are often used while native mosses are absent.

The aim of this study is to determine radionuclides activity level in Pleurozium schreberi transplanted from an unpolluted control site to an industrial study area.

\section{Material and methods}

Research sites were selected in the Upper Silesia (Fig. 1).

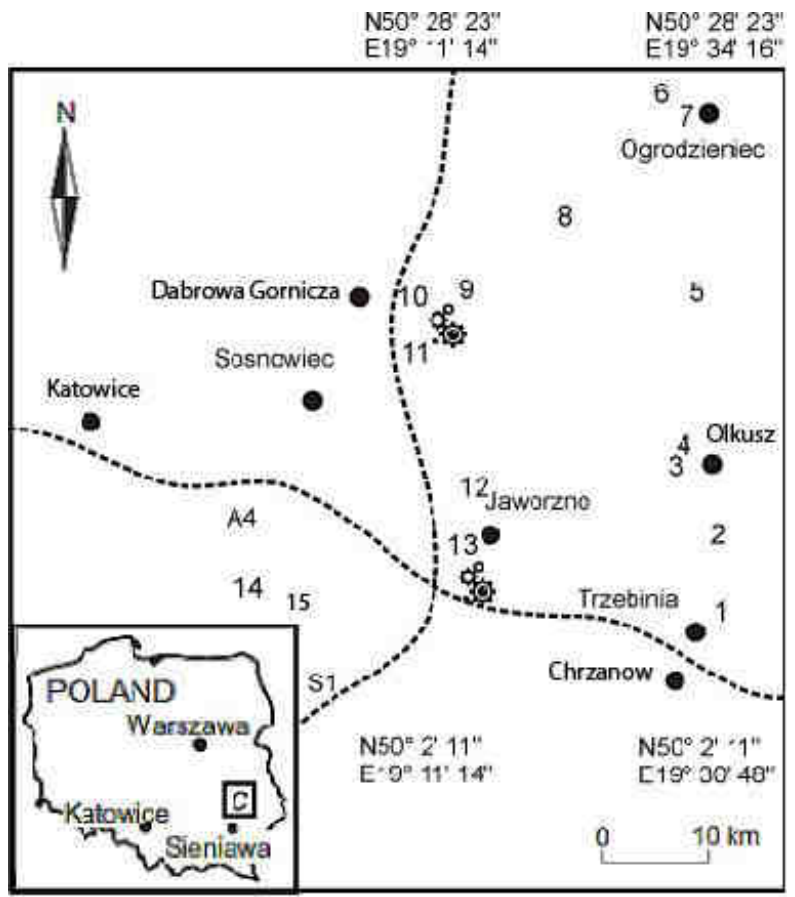

Fig. 1. Location of the sampling sites 
The sites were divided into categories: industrial areas, residential areas, areas close to major road junctions, the rural areas (4 each). Samples of native moss $P$. schreberi and soil were collected from all sites. Moss transplants, including the basis, were collected from the site considered as a control within a single population of mid-forest clearing in the pine forest, and placed in the same contaminated sites in Upper Silesia as in case of native mosses.

The measurement of radionuclide activity in plants and soils samples was carried out by means of a gamma-spectrometer with a germanium detector HPGe (Canberra) of high resolution: $1.29 \mathrm{keV}$ (FWHM) at $662 \mathrm{keV}$ and $1.70 \mathrm{keV}$ (FWHM) at $1332 \mathrm{keV}$. Relative efficiency: $21.7 \%$. Energy and efficiency calibration of the gamma spectrometer was performed with the standard solutions type MBSS 2 (Czech Metrological Institute, Praha), which covers an energy range from 59.54 to $1836.06 \mathrm{keV}$. The geometry of the calibration source was a Marinelli container $\left(447.7 \pm 4.5 \mathrm{~cm}^{3}\right)$, with density $0.99 \pm 0.01 \mathrm{~g} / \mathrm{cm}^{3}$, containing Am-241, Cd-109, Ce-139, Co-57, Co-60, Cs-137, Sn-113, Sr-85, Y-88 and Hg-203. The geometry of sample container was a similar Marinelli of $450 \mathrm{~cm}^{3}$. Time of measurement was $24 \mathrm{~h}$ for all of moss samples. Measuring process and analysis of spectra were computer controlled with the use of GENIE 2000 software.

\section{Results and discussions}

In laboratory analyses activity concentrations of the following gamma radioactive radioisotopes were determined: Ac-228, $\mathrm{Pb}-212, \mathrm{Bi}-212$ (thorium series), $\mathrm{Pb}-214, \mathrm{Bi}-214$, $\mathrm{Pb}-210$ (uranium-radium series), U-235, Th-321, Pb-211 (uranium-actinium series), K-40 and an artificial radioisotope Cs-137.

Table 1

Half-lifes $t_{1 / 2}$ of the determined radioisotopes [25]

\begin{tabular}{|c|c|c|c|c|c|c|c|c|c|c|c|}
\hline Nuclides & K-40 & $\begin{array}{c}\text { Cs- } \\
\mathbf{1 3 7}\end{array}$ & $\begin{array}{c}\text { Pb- } \\
\mathbf{2 1 0}\end{array}$ & Pb-211 & $\begin{array}{c}\text { Bi- } \\
\mathbf{2 1 2}\end{array}$ & Pb-212 & Bi-214 & $\begin{array}{c}\text { Pb- } \\
\mathbf{2 1 4}\end{array}$ & $\begin{array}{c}\text { Ac- } \\
\mathbf{2 2 8}\end{array}$ & $\begin{array}{c}\text { Th- } \\
\mathbf{2 3 1}\end{array}$ & U-235 \\
\hline \multirow{2}{*}{$\mathrm{T}_{1 / 2}$} & $\begin{array}{c}1.25 \cdot 10^{9} \\
\mathrm{a}\end{array}$ & $\begin{array}{c}30.1 \\
\mathrm{a}\end{array}$ & $\begin{array}{c}22.2 \\
\mathrm{a}\end{array}$ & $\begin{array}{c}36.1 \\
\mathrm{~min}\end{array}$ & $\begin{array}{c}25 \\
\mathrm{~min}\end{array}$ & $\begin{array}{c}10.64 \\
\mathrm{~h}\end{array}$ & $\begin{array}{c}19.9 \\
\mathrm{~min}\end{array}$ & $\begin{array}{c}26.8 \\
\mathrm{~min}\end{array}$ & $\begin{array}{c}6.15 \\
\mathrm{~h}\end{array}$ & $\begin{array}{c}25.52 \\
\mathrm{~h}\end{array}$ & $\begin{array}{c}703.8 \cdot 10^{6} \\
\mathrm{a}\end{array}$ \\
\hline
\end{tabular}

Among the radioisotopes determined, the most stable is $\mathrm{K}-40$, and the least stable, with half-lifes in range of several dozen of minutes, are $\mathrm{Pb}-211, \mathrm{Bi}-212, \mathrm{~Pb}-214, \mathrm{Bi}-214$.

In Figure 2 an illustration of measurements results is presented in box plots. Distribution of activity concentrations in the brown parts of moss are labeled with "br", the same parameter for green parts is labeled "gr", and for soil the "so" label is used. It was observed that distribution of logarithm of activity concentration is more symmetric than distribution of the crude results. This observation justifies application of logarithmic transformation of results in the variance analysis computations.

In comparison of mean activity concentration in groups of the materials types the oneway ANOVA method was applied.

If null hypothesis was rejected on $0.05 \alpha$ level then the Tukey post hoc test was applied to identify groups significantly different from the others.

The significance levels of the tests are encoded as follows: $0-0.05<\alpha$; $*$ - $0.05 \geq \alpha>0.01 ; * *-0.01 \geq \alpha>0.001 ; * * *-0.001 \geq \alpha$.

In Table 2 the statistical significance of differences between activity concentrations of radioisotopes in different materials are shown. 


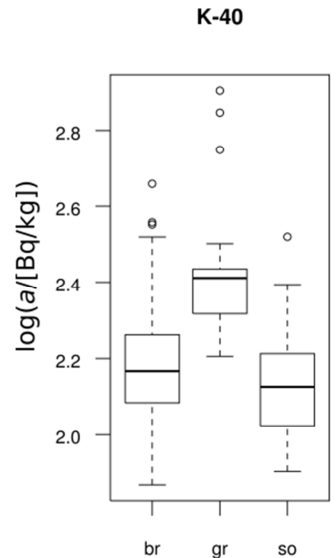

Cs-137

$\mathrm{Pb}-210$

Bi-212
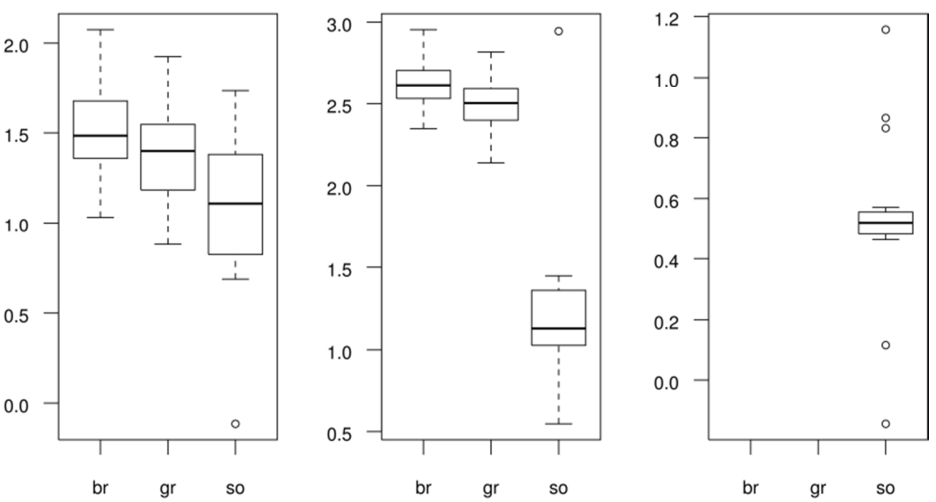

$\mathrm{Pb}-212$

$\mathrm{Bi}-214$

$\mathrm{Pb}-214$

Ac-228
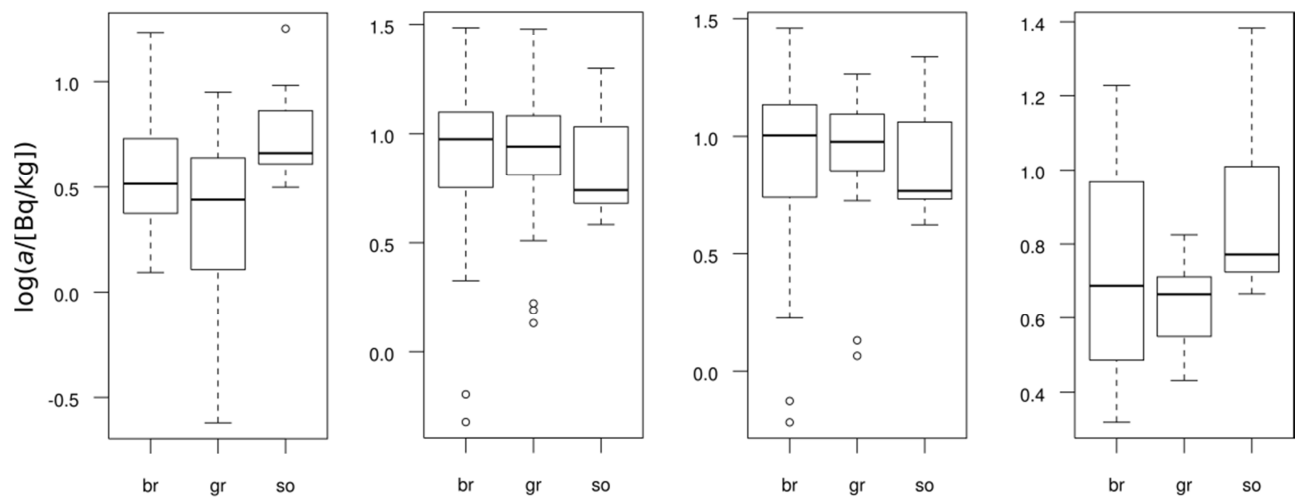

Th-231

U-235
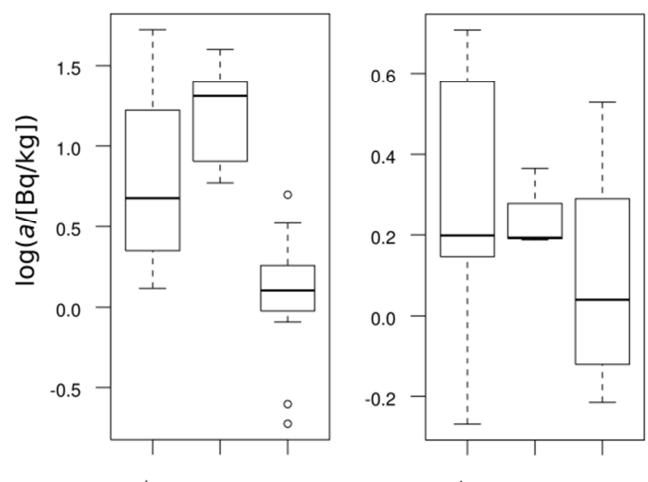

Fig. 2. Distribution of the radioisotopes logarithmic activity concentration in green (gr) and brown (br) parts of moss, and in soil (so) 
The statistical significance of differences between activity concentrations of radioisotopes in different materials

\begin{tabular}{|c|c|c|c|c|c|c|c|c|c|}
\hline & K-40 & Cs-137 & Pb-210 & Pb-212 & Bi-214 & Pb-214 & Ac-228 & Th-231 & U-235 \\
\hline ANOVA & $* * *$ & $* * *$ & $* * *$ & $* *$ & o & o & $*$ & $* * *$ & o \\
\hline gr-br & $* * *$ & $\mathrm{o}$ & $\mathrm{o}$ & $\mathrm{o}$ & & & $\mathrm{o}$ & $\mathrm{o}$ & \\
\hline so-br & $\mathrm{o}$ & $* * *$ & $* * *$ & $\mathrm{o}$ & & & $\mathrm{o}$ & $* *$ & \\
\hline so-gr & $* * *$ & $* *$ & $* * *$ & $* *$ & & & $*$ & $* * *$ & \\
\hline
\end{tabular}

The biggest radioactivity level in the samples was observed for K-40 and $\mathrm{Pb}-210$. It was even several times bigger than activity concentration of the other radioisotopes. Activity concentrations of $\mathrm{Pb}-212$ in moss were lower than the minimum detectable activity, MDA.

The data shown in Table 2 indicate similar character of radioisotopes accumulation in brown and green parts of moss. Only K-40 concentration was higher in the brown parts than in the green ones. In soil and green parts of moss activity concentrations of all radioisotopes determined were different.

Activity concentrations of some radioisotopes in soil and in the brown parts of moss are similar. Significant differences were observed in Cs-137, Pb-210 and Th-231 activity concentrations.

Despite the different material types and considerable distance between sampling sites, the sample's compositions were similar. Particularly, no significant differences in short living $\mathrm{Pb}-214$ and $\mathrm{Bi}-214$ activity concentrations in samples indicate uniform distribution of parent Ra-226, both spatial and in different materials. Similar homogeneous distribution was observed for U-235.

Boxplots in Figure 3 illustrate the data distribution in domestic D, transplanted $\mathrm{T}$ and control $\mathrm{C}$ moss groups, and in soil. For calculations the data regarding green and brown parts of moss were joined together.

In Table 3 the statistical significance of differences between activity concentrations of radioisotopes in different moss parts and in soil are shown.

Table 3

The statistical significance of differences between activity concentrations of radioisotopes in different moss parts and in soil

\begin{tabular}{|c|c|c|c|c|c|c|c|c|c|}
\hline & K-40 & Cs-137 & Pb-210 & Pb-212 & Bi-214 & Pb-214 & Ac-228 & Th-231 & U-235 \\
\hline ANOVA & $* *$ & $* * *$ & $* * *$ & $* * *$ & $* * *$ & $* * *$ & $* *$ & $*$ & $*$ \\
\hline D-C & $\mathrm{o}$ & $\mathrm{o}$ & $\mathrm{o}$ & $* * *$ & $* * *$ & $* * *$ & $*$ & & \\
\hline So-C & $\mathrm{o}$ & $\mathrm{o}$ & $* * *$ & $* * *$ & $* * *$ & $* * *$ & $* *$ & & \\
\hline $\mathrm{T}-\mathrm{C}$ & $\mathrm{o}$ & $\mathrm{o}$ & $\mathrm{o}$ & $* * *$ & $* * *$ & $* * *$ & $\mathrm{o}$ & & \\
\hline So-D & $* *$ & $* * *$ & $* * *$ & $\mathrm{o}$ & $\mathrm{o}$ & $\mathrm{o}$ & $\mathrm{o}$ & $* *$ & $\mathrm{o}$ \\
\hline $\mathrm{T}-\mathrm{D}$ & $\mathrm{o}$ & $\mathrm{o}$ & $\mathrm{o}$ & $\mathrm{o}$ & $\mathrm{o}$ & $\mathrm{o}$ & $\mathrm{o}$ & $\mathrm{o}$ & $\mathrm{o}$ \\
\hline T-So & $\mathrm{o}$ & $* *$ & $* * *$ & $\mathrm{o}$ & $\mathrm{o}$ & $\mathrm{o}$ & $\mathrm{o}$ & $* *$ & $\mathrm{o}$ \\
\hline
\end{tabular}

Statistically significant differences in compositions of the domestic (D) and the control (C) moss groups were found for $\mathrm{Pb}-212, \mathrm{Bi}-214, \mathrm{~Pb}-214$ and Ac-228. This result supposes similar concentrations of more stable parent radioisotopes, preceding the mentioned ones in decay series. For Pb-212 and Ac-228 it is Ra-228 $\left(t_{1 / 2}=5.8 \mathrm{a}\right)$ or Th-232 $\left(t_{1 / 2}=1.4 \cdot 10^{10} \mathrm{a}\right)$. More stable parent radioisotope preceding $\mathrm{Bi}-214$ and $\mathrm{Pb}-214$ is $\mathrm{Ra}-226\left(t_{1 / 2}=1599 \mathrm{a}\right)$. Activity concentrations of Th-213 and U-235 in moss samples belonging to the $\mathrm{C}$ and $\mathrm{D}$ groups were lower than MDA. 

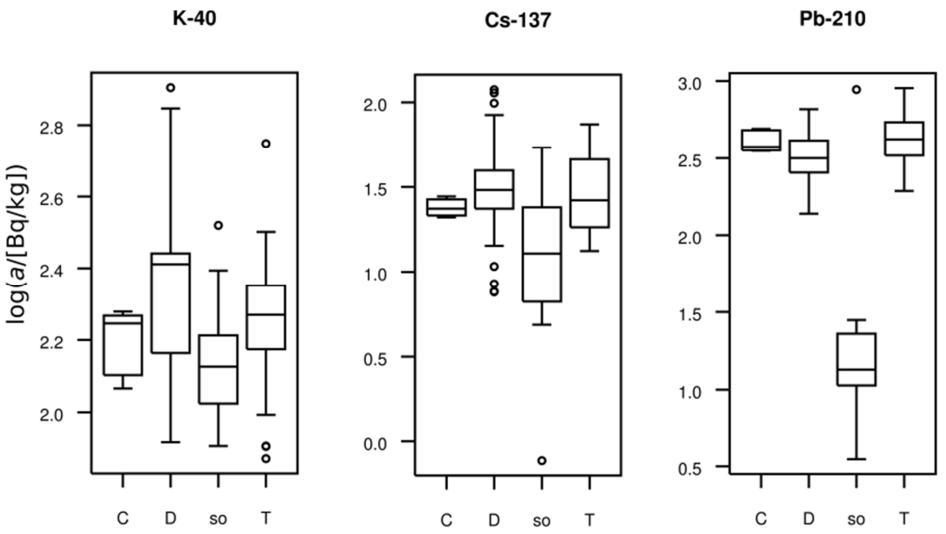

$\mathrm{Bi}-212$

$\mathrm{Pb}-212$

$\mathrm{Bi}-214$

$\mathrm{Pb}-214$

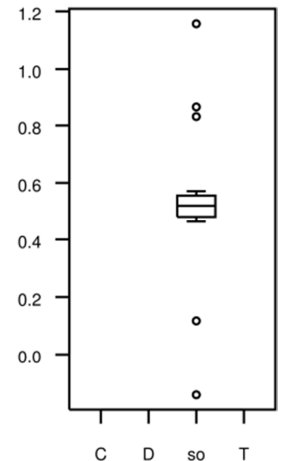

C D so $T$
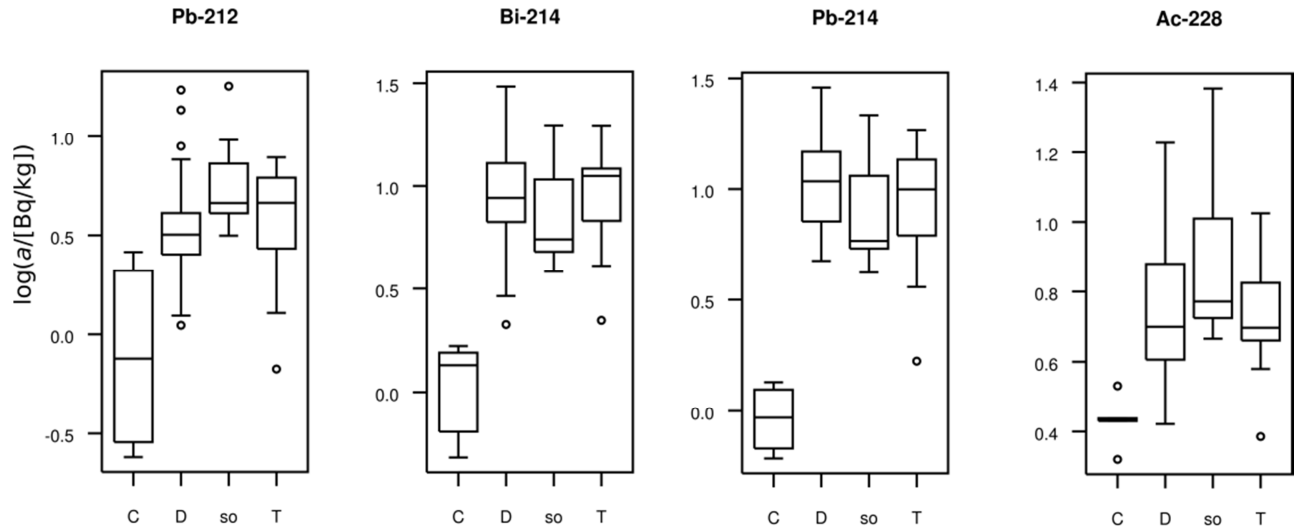

Th-231

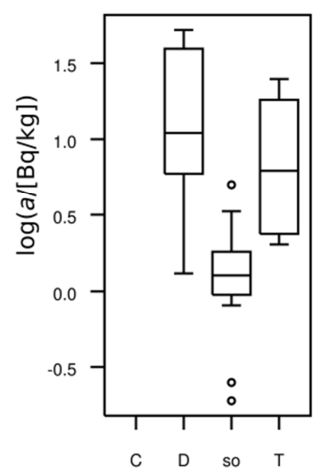

U-235

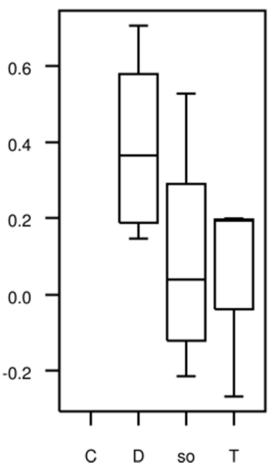

Fig. 3. Distribution of the radioisotopes logarithmic activity concentration in different moss samples (C - control, D - domestic, T - transplants, so - soil)

Compositions of the transplanted moss (T) and local (D) were similar to the ones in the $\mathrm{C}$ and D pair. While relatively constant content of K-40 is bound to physiological role of 
potassium in moss and a mechanism of self-regulation of its concentration occurs, the Cs-137 activity concentration is associated with the global relocation of this radioisotope. Similar $\mathrm{Pb}-210$ content also suppose influence of global sources of this radioisotope on the deposit's composition.

No significant differences in radioisotopes concentration in transplanted and local moss samples indicate unification of their composition during exposure period.

In the collected samples the state of radioactive equilibrium was assessed. Usually activity concentrations of radioisotopes belonging to the same decay series were proportional, what illustrates relation between $\mathrm{Pb}-214$ and $\mathrm{Bi}-214$ activity concentrations, shown in Figure 4.

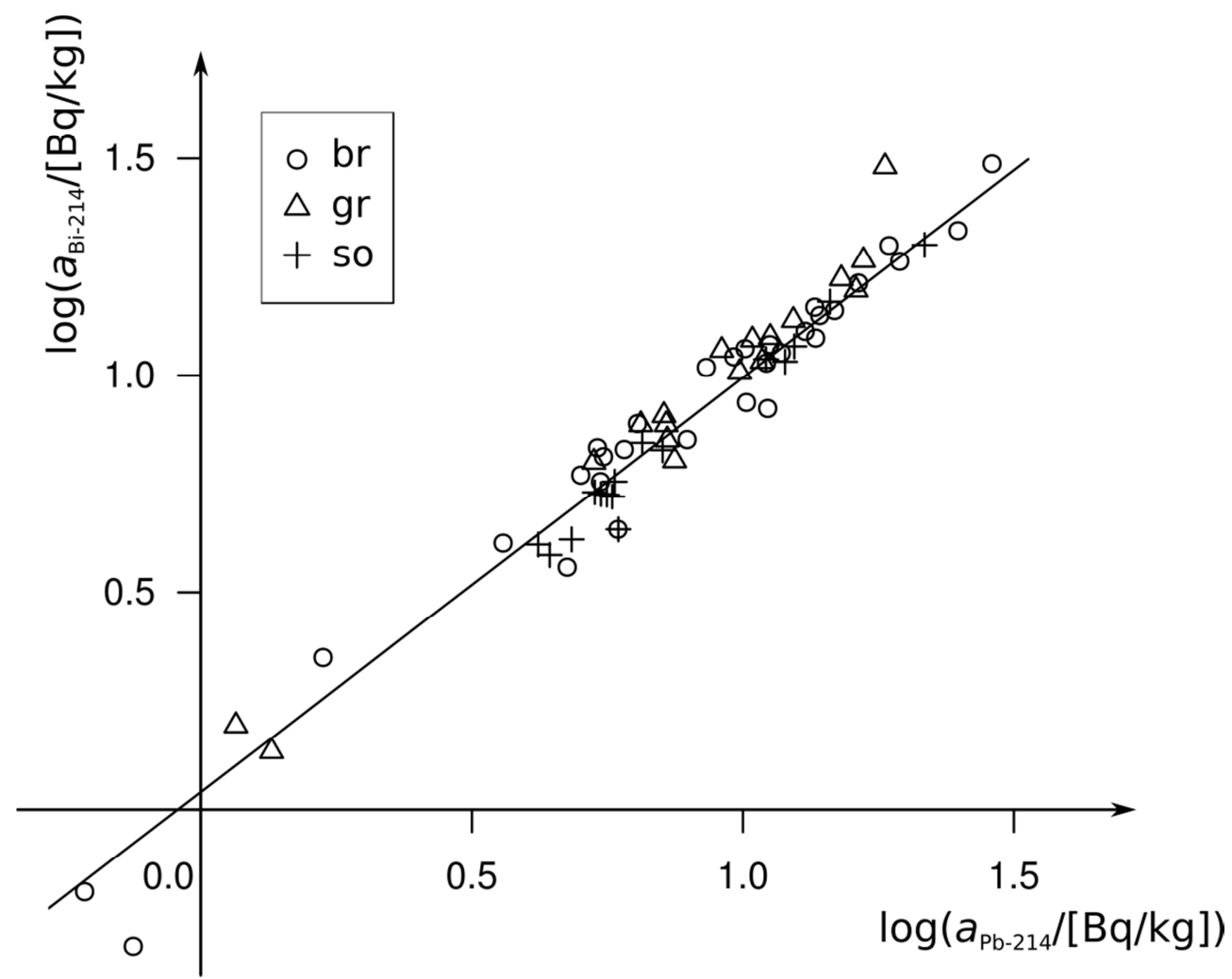

Fig. 4. Relationship between $\mathrm{Bi}-214$ and $\mathrm{Pb}-214$ activity concentrations in the materials studied

An exception was $\mathrm{Pb}-210$, which activity concentration was not related to the one for Bi-214. The relationship between activity concentration of these radioisotopes is illustrated in Figure 5. Individual points on the graph are identified by the shape of the symbol (type of material) and a letter description (location of sampling site). The dotted line shows the same activity concentration of both radioisotopes.

No significant difference in character of the $\mathrm{Pb}-210$ and $\mathrm{Bi}-214$ activity concentrations relation in brown and green parts of moss was observed. Points representing these materials 
form approximately uniform groups, also in respect to sampling point location. The control group points create the separate cluster.

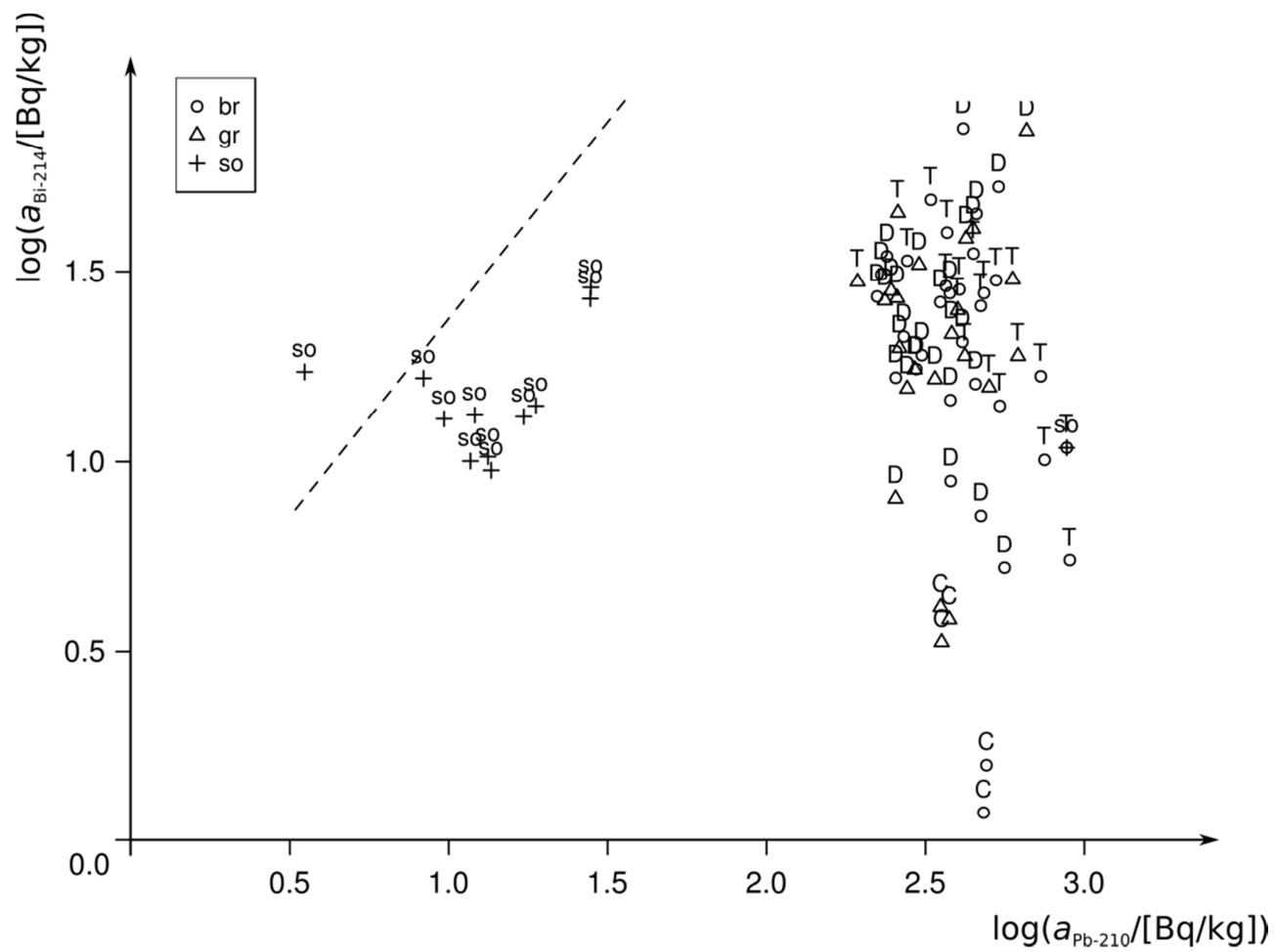

Fig. 5. The relationship between $\mathrm{Bi}-214$ and $\mathrm{Pb}-210$ activity concentrations in the studied materials

The points representing $\mathrm{Pb}-210$ and $\mathrm{Bi}-214$ activity concentrations in soil form separate group. With an exception of a single point, the remaining ones represent samples in which $\mathrm{Pb}-210$ activity concentration was bigger than the one for $\mathrm{Bi}-214$. But this difference was clearly lower than that in moss.

No correspondence of $\mathrm{Pb}-210$ activity concentration with the activities of daughter radioisotopes belonging to uranium-radium series, i.e. Bi-214, suggests the existence of an excess $\mathrm{Pb}-210$. An atmospheric precipitation could be a source of additional $\mathrm{Pb}-210$. The particulate material is deposited on the surface of the green parts of mosses and in surface soils. Penetrating slightly into the substrate, the material also enters the relatively shallow located brown parts of mosses. But $\mathrm{Pb}-210$ remains at the surface of the soil. This conclusion is supported by lower activity concentration of this radioisotope in 10-cm layer of soil.

During the sample's collection the deeper layers (containing less $\mathrm{Pb}-210$ ) and shallow (enriched with $\mathrm{Pb}-210$ ) are mixed, resulting in a reduction of the radioisotope activity concentration in the material processed. 


\section{Conclusions}

The following conclusions can be drawn from the data analysis:

- The expected relationship between activity concentrations of $\mathrm{Pb}-210$ and $\mathrm{Pb}-214$ or Bi-214 was not observed. Increased activity of $\mathrm{Pb}-210$ in $P$. schreberi may be the result of the atmospheric deposition of the radioisotope, which appears in atmosphere as a result of fossil fuels burning.

- The excess, allogeneic $\mathrm{Pb}-210$ can be regarded as a marker of environmental pollution. In the areas with higher $\mathrm{Pb}-210$ activity concentration, existence of atmospheric pollution sources can be expected.

- It has been found that increasing activity concentration of radioisotopes in P. schreberi transplanted from uncontaminated sites to industrial areas may indicate not only the deposition of radioisotopes, but also an inflow of other pollutants.

\section{References}

[1] AMAP Assessment 2002: Radioactivity in the Arctic. Arctic Monitoring and Assessment Programme (AMAP). Oslo, Norway: 2004. http://www.amap.no/, accessed 10.12.2016.

[2] Mietelski JW, Olech MA, Sobiech-Matura K, Howard BJ, Gaca P, Zwolak M, et al. ${ }^{137} \mathrm{Cs},{ }^{40} \mathrm{~K},{ }^{238} \mathrm{Pu}$, ${ }^{239+240} \mathrm{Pu}$ and ${ }^{90} \mathrm{Sr}$ in biological samples from King George Island (Southern Shetlands) in Antarctica. Polar Biol. 2008;31:1081-1089. DOI: 10.1007/s00300-008-0449-5.

[3] Paatero J, Vira J, Siitari-Kauppi M, Hatakka J, Holmén K, Viisanen Y. Airborne fission products in the high Arctic after the Fukushima nuclear accident. J Environ Radioac. 2012;114:41-47. DOI: 10.1016/j.jenvrad.2011.12.027.

[4] Smith JN. ${ }^{239,240} \mathrm{Pu}$ transport into the Arctic Ocean from underwater nuclear tests in Chernaya Bay, Novaya Zemlya. Continent. Shelf Res. 2000;20:255-279. DOI: 10.1016/S0278-4343(99)00066-7.

[5] Michalik B, Brown J, Krajewski P. The fate and behaviour of enhanced natural radioactivity with respect to environmental protection. Environ Impact Assess Rev. 2013;38:163-171. DOI: 10.1016/j.eiar.2012.09.001.

[6] Olszowski T. Changes in $\mathrm{PM}_{10}$ concentration due to large-scale rainfall. Arab J Geosci. 2016;9:160. DOI: $10.1007 / \mathrm{s} 12517-015-2163-2$

[7] Alonso-Hernandez C, Guillen-Arruebarrena A, Cartas-Aguila A, Morera-Gomez Y, Diaz-Asencio M. Observations of fallout from the Fukushima Reactor Accident in Cienfuegos, Cuba. Bull En. Contam Toxic. 2012;88:752-754. DOI: 10.1007/s00128-012-0542-x.

[8] Ioannidou A, Manenti S, Gini L, Groppi F. Fukushima fallout at Milano, Italy. J Environ Radioact. 2012;114:119-125. DOI: 10.1016/j.jenvrad.2012.01.006.

[9] Conti ME, Cecchetti G. Biological monitoring: lichens as bioindicators of air pollution assessment a review. Environ Pollut. 2001;114:471-492. DOI: 10.1016/S0269-7491(00)00224-4.

[10] Lukšienė B, Marčiulionienė D, Gudelienè I, Schönhofer F. Accumulation and transfer of ${ }^{137} \mathrm{Cs}$ and ${ }^{90} \mathrm{Sr}$ in the plants of the forest ecosystem near the Ignalina Nuclear Power Plant. J Environ Radioact. 2013;116:1-9. DOI: 10.1016/j.jenvrad.2012.09.00 5.

[11] Yoshihara T, Matsumura H, Hashida SN, Nagaoka T. Radiocesium contaminations of 20 wood species and the corresponding gamma-ray dose rates around the canopies at 5 months after the Fukushima nuclear power plant accident. J Environ Radioact. 2013;115:60-68. DOI: 10.1016/j.jenvrad.2012.07.002.

[12] Todorović D, Popović D, Ajtić J, Nikolić J. Leaves of higher plants as biomonitors of radionuclides $\left({ }^{137} \mathrm{Cs},{ }^{40} \mathrm{~K},{ }^{210} \mathrm{~Pb}\right.$ and $\left.{ }^{7} \mathrm{Be}\right)$ in urban air. Environ Sci Pollut Res. 2012;20:525-532. DOI: 10.1007/s11356-012-0940-y.

[13] Szczepaniak K, Biziuk M. Aspects of the biomonitoring studies using mosses and lichens as indicators of metal pollution. Environ Research. 2003;93:221-230. DOI: 10.1016/S0013-9351(03)00141-5.

[14] Ares A, Aboal JR, Carballeira A, Giordano S, Adamo P, Fernandez JA. Moss bag biomonitoring a methodological review. Sci Total Environ. 2012;432:143-158. DOI: 10.1016/j.scitotenv.2012.05.087.

[15] Bleise A, Smodis B. Internationally Harmonized Approach to Biomonitoring Trace Element Atmospheric Deposition. Joint Institute for Nuclear Research, Advanced Research Workshop, Monitoring of Natural and Man-Made Radionuclides and Heavy Metal Waste in Environment, 3-6 October 2000. Dubna, Russia.

[16] Steinnes E. Use of mosses to study atmospheric deposition of trace elements: Contributions from investigations in Norway. Internat J Environ Pollut. 2008;32:499-508. DOI: 10.1504/IJEP.2008.018413. 
[17] Suchara I, Sucharova J, Hola M, Reimann C, Boyd R, Filzmoser P, et al. The performance of moss, grass, and 1- and 2-year old spruce needles as bioindicators of contamination: A comparative study at the scale of the Czech Republic. Sci. Total Environ. 2011;409:2281-2297. DOI: 16/j.scitotenv.2011.02.003.

[18] Krmar M, Radnovic D, Mihailovic DT, Lalic B, Slivka J, Bikit I. Temporal variations of ${ }^{7} \mathrm{Be},{ }^{210} \mathrm{~Pb}$ and ${ }^{137} \mathrm{Cs}$ in moss samples over 14 month period. Appl Radiat Isot. 2009;67:1139-1147. DOI: 10.1016/j.apradiso.2009.01.001.

[19] Ziembik Z, Dołhańczuk-Środka A, Majcherczyk T, Wacławek M. Illustration of constrained composition statistical methods in the interpretation of radionuclide concentrations in the moss Pleurozium schreberi. J Environ Radioact. 2013;117:13-18. DOI: 10.1016/j.jenvrad.2012.04.002.

[20] Dołhańczuk-Śródka A, Ziembik Z, Wacławek M, Hyšplerová L. Transfer of cesium-137 from forest soil to moss Pleurozium schreberi. Ecol Chem Eng S. 2011;18(4):509-516. http://tchie.uni.opole.pl/freeECE/S_18_4/DolhanczukSrodkaZiembik_18(S4).pdf.

[21] Kłos A, Rajfur M, Czora M, Wacławek M. Mechanisms for translocation of heavy metals from soil to epigeal mosses. Water Air Soil Pollut. 2012;223:1829-1836. DOI: 10.1007/s11270-011-0987-2.

[22] Kosior G, Samecka-Cymerman A, Chmielewski A, Wierzchnicki R, Derda M, Kempers AJ. Native and transplanted Pleurozium schreberi (Brid.) Mitt. as a bioindicator of $\mathrm{N}$ deposition in a heavily industrialized area of Upper Silesia (S Poland). Atmos Environ. 2008;42(6):1310-1318. DOI: 10.1016/j.atmosenv.2007.10.086.

[23] Samecka-Cymerman A, Kolon K, Kempers AJ. A comparison of native and transplanted Fontinalis antipyretica Hedw. as biomonitors of water polluted with heavy metals. Sci Total Environ. 2005;341:97-107. DOI: 10.1016/j.scitotenv.2004.09.026.

[24] Ciesielczuk T, Olszowski T, Prokop M, Kłos A. Application of mosses to identification of emission sources of polycyclic aromatic hydrocarbons. Ecol Chem Eng S. 2012;19(4):585-595. DOI: 10.2478/v10216-011-0041-8.

[25] http://www.nndc.bnl.gov/nudat2/ 